\title{
Market Power in the European Dairy Industry
}

L. Čechura1 ${ }^{1}$ Z. Žáková Kroupová1 ${ }^{1}$ H. Hockmann²

${ }^{1}$ Department of Economics, Faculty of Economics and Management, Czech University of Life Sciences Prague, Czech Republic

${ }^{2}$ IAMO, Agricultural Markets, Marketing and World Agricultural Trade, Halle, Germany

\begin{abstract}
Anotace
Článek je zaměřen na analýzu tržní síly na trhu mléčných výrobků. Konkrétně článek identifikuje tržní sílu zpracovatelského trhu mléka ve 24 zemích Evropské unie. Analýza tržní síly je založena na tzv. mark-up modelu a aplikaci př́stupu stochastické hraniční funkce. Výsledky prokazují tržní selhání na zpracovatelském trhu mléka v Evropské unii. Zmíněné zneužití oligopolní tržní síly není v průměru velké. Mezi analyzovanými zeměmi však existují významné rozdíly. Rozdělení tržní síly je sešikmené směrem k nižším hodnotám, což znamená, že většina společností disponuje nízkou nebo téměř žádnou tržní silou. Na druhou stranu zde však existují i společnosti (okolo 10 \%) se značně vysokou tržní silou.
\end{abstract}

\section{Klíčová slova}

Mléko, tržní síla, oligopol, SFA, Evropská unie.

\begin{abstract}
The paper presents an analysis of market power in the output milk-processing market. In particular, the paper identifies market failures in the output milk-processing market in $24 \mathrm{EU}$ member states. The analysis is based on a mark-up model and the application of stochastic frontier methodology. The results show that market failures are pronounced on the EU output milk-processing market. However, the abuse of oligopoly market power is not large on average, despite the fact that we can find significant differences among the countries. The mark-up distribution is skewed toward lower values. That is, the majority of companies are characterized by only a small or almost no degree of market power; however, there are companies (about $10 \%$ ) with considerably high oligopoly market power.
\end{abstract}

\section{Keywords:}

Milk, market power, oligopoly, SFA, European Union.

Čechura, L., Žáková Kroupová, Z. and Hockmann, H. (2015) "Market Power in the European Dairy Industry", AGRIS on-line Papers in Economics and Informatics, Vol. 7, No. 4, pp. 39 - 47, ISSN 1804-1930.

\section{Introduction}

Market power is defined as the ability of a firm or group of firms to raise the price of a good or service above the competitive level (Kutlu and Sickles, 2012). Morrison Paul (2001) added that evaluating market power involves modelling and measuring the difference between market price and marginal factor cost for inputs (mark-down), or price and marginal cost for outputs (mark-up). Since 1980 there have been numerous studies based on a New Empirical Industrial Organization theoretical background focused on detecting market power or, in general, market imperfections in the agricultural or food-processing market, as the case may be. Most of these studies are based on the Lerner index (Lerner, 1934). Nevertheless, Kumbhakar et al. (2012) point out several weaknesses of this approach, namely the optimization errors, possibility of negative market power, assumption of constant returns to scale and price data requirement. Another approach for measuring market power is to estimate a conduct parameter rather than use the Lerner index (Kutlu and Sickles, 2012, Muth and Wohlgenant, 1999). This approach uses a conjectural variations 
approach and treats the conduct as a parameter to be estimated. Finally, Kumbhakar et al. (2012) introduced an approach based on stochastic frontier analysis.

The results of previous studies mostly found that food processors have oligopsony market power (e.g. Morrison Paul, 2000), but there are also studies which failed to find any evidence of oligopsony power (e.g. Muth and Wohlgenant, 1999, Perekhozhuk and Grings, 2006) or found only weak oligopsony power (Scalco and Brage, 2014). Moreover, McCorriston (2002) concluded that food markets are now more typically oligopolistic. Studies using firm-level data are not so numerous and include, for example, Hockmann and Vöneki (2009), Bakucs et al. (2009), Perekhozhuk et al. (2013) and Acharya et al. (2011).

This paper extends the above-mentioned studies on the analysis of market imperfections. The aim is to conduct a comparative analysis among the EU member countries and identify the degree of market imperfections in the output milkprocessing market. In particular, the paper addresses the following research questions. The first question concerns market imperfections in the output milkprocessing market. The aim is to identify the degree of oligopoly market power. The second question relates to the country specifics, especially whether output milk-processing markets differ significantly among EU countries, and what the development is in the analysed period.

The paper is organized as follows: the Materials and methods section presents the estimation strategy and describes the data set; the Results and discussion section presents the results of the markup model and the relative mark-up in EU member states; and the Conclusions section contains concluding remarks.

\section{Materials and methods}

The research questions will be addressed by estimating a mark-up model and employing stochastic frontier methodology. The mark-up model is derived from the standard profit maximization problem. The solution of the optimization problem results in product price equalling marginal costs for a competitive market, and price exceeding marginal costs for a non-competitive (oligopolistic) market:

$p \geq \frac{\partial C\left(\mathbf{w}, y_{i}, t\right)}{\partial y_{i}}$,

where $p$ is a price of output (product), $Y$ is an output, and $C$ stands for total costs.

If we multiply relation (1) by the share of output on total costs, we can write:

$\frac{p \cdot y}{C} \geq \frac{\partial C\left(\mathbf{w}, y_{i}, t\right)}{\partial y_{i}} \cdot \frac{y}{C}=\frac{\partial \ln C}{\partial \ln y}$,

The inequality can be transformed to an equality by adding a non-negative, one-sided error term $(u)$, i.e. $u$ represents a measure of market failures - relation (3). Then, relation (3) can be estimated using stochastic frontier methodology. The stochastic frontier approach for detecting the degree of monopoly power was first introduced by Kumbhakar et al. (2012).

$\frac{p \cdot y}{C}=\frac{\partial \ln C}{\partial \ln y}+u, u \geq 0$,

Relation (3) asks for estimation of the first derivative of the cost function. If the database does not contain prices, the duality theorem can be employed, and the first derivative of the input distance function can be estimated instead (Kumbhakar et al., 2012):

$\frac{p \cdot y}{C}=\frac{\partial \ln C}{\partial \ln y}+u=\frac{\partial \ln D^{I}}{\partial \ln y}+u, u \geq 0$,

Assuming that the input distance function has a translog form:

$$
\begin{aligned}
\ln D^{I}= & \alpha_{0}+\alpha_{t} t+\frac{1}{2} \alpha_{t t} t^{2}+\alpha_{y} \ln y+\alpha_{y t} \ln y t+\frac{1}{2} \alpha_{y y}(\ln y)^{2} \\
& +\boldsymbol{\alpha}_{x} \ln \widetilde{\mathbf{x}}+\boldsymbol{\alpha}_{x t} \ln \widetilde{\mathbf{x}} t+\frac{1}{2} \ln \widetilde{\mathbf{x}}^{\prime} \mathbf{A}_{x x} \ln \widetilde{\mathbf{x}}+\ln \widetilde{\mathbf{x}}^{\prime} \mathbf{A}_{x y} \ln y
\end{aligned}
$$

where $\tilde{x}_{j}=x_{j} / x_{J}$ for $j=1, \ldots, J-1$, are normalized input quantities and $T$ is a time variable, then adding a variable capturing the statistical noise $(v)$, we get:

$\frac{\partial \ln D^{I}}{\partial \ln y}=\alpha_{y}+\alpha_{y t} t+\alpha_{y y} \ln y+\boldsymbol{\alpha}_{x y} \ln \widetilde{\mathbf{x}}+u+v$,

That is, the model estimated in the empirical part has the form:

$\frac{p \cdot y}{C}=\alpha_{y}+\alpha_{y t} t+\alpha_{y y} \ln y+\boldsymbol{\alpha}_{x y} \ln \widetilde{\mathbf{x}}+u+v$,

Defining the relative mark-up $(\varphi)$ as $\varphi=\frac{p-M C}{M C}$ we
get the estimate of relative mark-up as: $\hat{\varphi}=\frac{\hat{u}}{\alpha_{y}+\alpha_{y t} t+\alpha_{y y} \ln y+\alpha_{y x}{ }^{\prime} \ln \mathbf{x}}$

Moreover, since we respect the heterogeneity in production structures we employ the extended version of the random parameter model (Tsionas, 2002) and the fixed management model (Alvarez et al., 2003 and 2004); that is, relation (7) becomes: 


$$
\begin{aligned}
& \frac{p \cdot y}{C}=\alpha_{y}+\alpha_{y t} t+\alpha_{y y} \ln y_{i t}+\boldsymbol{\alpha}_{x y} \ln \widetilde{\mathbf{x}}_{i t} \\
& +\alpha_{m} m_{i}^{*}+\frac{1}{2} \alpha_{m m} m_{i}^{* 2}+\alpha_{t m} m_{i}^{*} t+\alpha_{y m} m_{i}^{*} y_{i t}+\boldsymbol{\alpha}_{x m} m_{i}^{*} \ln \widetilde{\mathbf{x}}_{i t}+u_{i t}+v_{i t},
\end{aligned}
$$

where $m_{i}^{*} \sim \bullet(0,1)$ represents unobservable heterogeneity (the symbol represents that $m_{i}{ }^{*}$ could possess any distribution with zero mean and unit variance). Subscripts $i$ and $t$ stand for the i-th producer at time $t$. Model (9) is fitted by maximum simulated likelihood with the software NLOGIT 5.0. $u_{i t}$ is estimated according to Jondrow et al. (1982).

The data we use in the analysis is drawn from the Amadeus database, which contains financial information for public and private companies across Europe. The database provides detailed information about (standardised) annual accounts, financial ratios, sectoral activities and ownership information. The panel data set that we use in our analysis contains companies whose main activity is milk processing, according to the NACE classification. It is an unbalanced panel data set, which represents the period from 2003 to 2012 and contains 6,367 observations of milk-processing companies from 24 EU countries (only Croatia, Cyprus, Luxembourg and Malta are missing).

The following variables were used in the analysis:

Revenue share $=$ Revenue $/$ Costs, Output, normalized Material and Labour. Revenue is represented by the operating revenue (Turnover) of the company. Costs are the sum of Labour costs, Material costs and Capital costs. Labour costs are represented by the cost of employees, Material costs are the total costs of materials and energy consumption per company, and Capital costs are calculated as the book value of fixed assets multiplied by the interest rate according to convergence criteria. Output is represented by operating revenue (Turnover) of the company and is deflated by the sectoral index of milk-processing prices (EU-level - 27 countries or country-level if it was disposable, respectively; $2010=100$ ). Material and Labour are normalized by Capital. Material is the total costs of materials and energy deflated by the index of producer prices in the milk industry (country-level; $2010=100$ ). Labour is represented by the total number of employees and Capital is the book value of fixed assets deflated by the index of producer prices in the industry (country-level; $2010=100)$.

Moreover, we rejected producers with fewer than three observations (on average) to decrease the problem associated with the entry and exit of producers from the database. The country sample descriptive statistics are provided in the Appendix - Table A1.

\section{Results and discussion}

Table 1 provides a parameter estimate of the mark-up model for the milk output processing market in the 24 EU member states. As expected, almost all parameters are highly significant. The only exceptions are the time variable and material in interaction with the heterogeneity component. Moreover, the high significance of most of the coefficients of the unobservable heterogeneity component (fixed management) confirms that the chosen specification approximates well the estimated relationship. That is, the heterogeneity among firms is an important characteristic of the milk food-processing sector.

The estimates show the positive impact of the output and labour inputs on revenue share in the milk food-processing sector. On the other hand, material inputs determine negatively the revenue share. This is in line with our expectations. Higher labour inputs are connected

\begin{tabular}{|l|c|c|c|l|l|l|c|}
\hline \multicolumn{4}{|l|}{ Means for random parameters } & \multicolumn{4}{l|}{ Coefficient on unobservable fixed management } \\
\hline Variable & Coeff. & \multicolumn{1}{l|}{ SE } & $\mathrm{P}\left[|\mathbf{z}|>Z^{*}\right]$ & Variable & Coeff. & SE & $\mathrm{P}\left[|\mathrm{z}|>Z^{*}\right]$ \\
\hline Const. & 1.1384 & 0.0069 & 0.0000 & Alpha_m & 0.9056 & 0.0081 & 0.0000 \\
\hline Time & 0.0001 & 0.0003 & 0.6680 & Time & -0.0025 & 0.0003 & 0.0000 \\
\hline Output & 0.0122 & 0.0007 & 0.0000 & Output & -0.0832 & 0.0008 & 0.0000 \\
\hline Labour & 0.0454 & 0.0009 & 0.0000 & Labour & -0.0167 & 0.0009 & 0.0000 \\
\hline Material & -0.0490 & 0.0009 & 0.0000 & Material & 0.0006 & 0.0009 & 0.5184 \\
\hline & & & & Alpha_mm & 0.2986 & 0.0018 & 0.0000 \\
\hline Sigma & 0.1252 & 0.0005 & 0.0000 & Lambda & 1.8631 & 0.0213 & 0.0000 \\
\hline
\end{tabular}

Source: own calculation 
with a production characterized by higher value added. The opposite can be expected for material inputs, ceteris paribus. Finally, the firms with higher output have a higher revenue share. This could also be connected with higher market power.

The unobservable heterogeneity component (management) contributes positively to the revenue share. Moreover, this positive impact is accelerating. As far as the relation between management and the mark-up component is concerned, we can conclude that an increase in the heterogeneity component (management) leads to a decrease in the mark-up component. Moreover, higher output leads to a smaller mark-up component for a given level of management. Labour determines negatively the mark-up component, and the material inputs are not statistically significant. The impact of time on market imperfections is negative, although very low. These results may suggest slightly increasing competitiveness in the EU food-processing output market in the dairy sector.
Finally, the parameter $\lambda$ is highly significant, and greater than one. That is, the estimate indicates that non-competitive behaviour can be found in the EU output milk-processing market. Moreover, the variation in the mark-up component $u_{i t}$ is more pronounced than the variation in the random component (statistical noise) $v_{i t}$, which suggests significant differences in the market behaviour among milk processors.

Table 2 presents the estimates of relative markup for European milk processors. The relative mark-up takes values in the interval from zero to one. Zero indicates competitive behaviour on the output market, as the case may be, i.e. the situation where marginal cost equals the price of the output. Then, a relative mark-up value higher than zero represents non-competitive behaviour. In particular, an increasing relative mark-up is associated with increasing market failures or the oligopolistic power of milk processors, respectively. The results show that the estimated

\begin{tabular}{|c|c|c|c|c|c|c|c|c|c|}
\hline & Mean & Std.Dev & Min. & Max. & $1^{\text {st }}$ decile & $9^{\text {th }}$ decile & $1^{\text {st }}$ quartile & $3^{\text {rd }}$ quartile & Cases \\
\hline EU & 0.121 & 0.074 & 0.004 & 0.875 & 0.047 & 0.210 & 0.073 & 0.151 & 6287 \\
\hline Austria & 0.152 & 0.046 & 0.076 & 0.291 & 0.106 & 0.211 & 0.117 & 0.176 & 37 \\
\hline Belgium & 0.134 & 0.056 & 0.014 & 0.323 & 0.074 & 0.226 & 0.103 & 0.158 & 274 \\
\hline Bulgaria & 0.088 & 0.082 & 0.017 & 0.441 & 0.025 & 0.214 & 0.033 & 0.101 & 79 \\
\hline Czech Republic & 0.103 & 0.062 & 0.007 & 0.443 & 0.044 & 0.181 & 0.061 & 0.129 & 278 \\
\hline Germany & 0.127 & 0.056 & 0.009 & 0.328 & 0.056 & 0.199 & 0.092 & 0.157 & 404 \\
\hline Denmark & 0.120 & 0.044 & 0.067 & 0.255 & 0.077 & 0.153 & 0.095 & 0.134 & 15 \\
\hline Estonia & 0.105 & 0.048 & 0.027 & 0.231 & 0.048 & 0.165 & 0.062 & 0.138 & 43 \\
\hline Spain & 0.126 & 0.077 & 0.008 & 0.552 & 0.046 & 0.225 & 0.074 & 0.163 & 569 \\
\hline Finland & 0.150 & 0.053 & 0.068 & 0.300 & 0.096 & 0.234 & 0.106 & 0.185 & 84 \\
\hline France & 0.138 & 0.069 & 0.004 & 0.463 & 0.054 & 0.226 & 0.095 & 0.176 & 619 \\
\hline United Kingdom & 0.077 & 0.044 & 0.008 & 0.308 & 0.034 & 0.128 & 0.046 & 0.098 & 447 \\
\hline Greece & 0.112 & 0.059 & 0.013 & 0.332 & 0.052 & 0.192 & 0.074 & 0.144 & 203 \\
\hline Hungary & 0.162 & 0.115 & 0.050 & 0.544 & 0.076 & 0.304 & 0.087 & 0.193 & 64 \\
\hline Italy & 0.136 & 0.077 & 0.007 & 0.646 & 0.055 & 0.228 & 0.088 & 0.166 & 1656 \\
\hline Ireland & 0.076 & 0.025 & 0.044 & 0.121 & 0.047 & 0.114 & 0.055 & 0.090 & 17 \\
\hline Latvia & 0.108 & 0.050 & 0.012 & 0.277 & 0.061 & 0.165 & 0.073 & 0.131 & 70 \\
\hline Lithuania & 0.086 & 0.044 & 0.021 & 0.206 & 0.041 & 0.162 & 0.050 & 0.112 & 99 \\
\hline Netherlands & 0.182 & 0.080 & 0.041 & 0.496 & 0.112 & 0.269 & 0.132 & 0.227 & 60 \\
\hline Poland & 0.097 & 0.056 & 0.009 & 0.427 & 0.051 & 0.154 & 0.067 & 0.108 & 749 \\
\hline Portugal & 0.157 & 0.072 & 0.005 & 0.334 & 0.078 & 0.259 & 0.103 & 0.206 & 75 \\
\hline Romania & 0.119 & 0.123 & 0.010 & 0.875 & 0.024 & 0.238 & 0.048 & 0.141 & 305 \\
\hline Sweden & 0.084 & 0.045 & 0.014 & 0.217 & 0.036 & 0.140 & 0.046 & 0.105 & 27 \\
\hline Slovenia & 0.125 & 0.040 & 0.067 & 0.210 & 0.080 & 0.182 & 0.098 & 0.149 & 27 \\
\hline Slovakia & 0.100 & 0.044 & 0.032 & 0.263 & 0.049 & 0.151 & 0.067 & 0.121 & 86 \\
\hline
\end{tabular}

Source: own calculation 
overall mean of the relative mark-up is 0.12 . That is, the European milk-processing output market is characterized by some degree of market failure or abuse of market power, as the case may be. Since the distribution of the mark-up is relatively narrow, with a standard deviation of 0.07 , and skewed toward smaller values, the majority of milk processors are characterized by only a small or almost no degree of market power. However, significant differences between the $1^{\text {st }}$ and $9^{\text {th }}$ deciles can be found. The first decile indicates that $10 \%$ of producers are very close to competitive behaviour (mark-up lower than 0.05). On the other hand, the last $10 \%$ of producers reach a relative mark-up higher than 0.21 . That is, the results indicate a considerable degree of non-competitive behaviour on the dairy output market for these producers.

The overall means of the relative mark-up differ among the individual member states. The means of the relative mark-up can be found in the interval 0.08 to 0.18 , and their standard deviations take values from 0.025 to 0.123 . Producers in Bulgaria (0.09), the United Kingdom (0.08), Ireland (0.076), Lithuania (0.09) and Sweden (0.08) exercise a lower degree of non-competitive behaviour, on average, as compared to producers in Austria (0.15), Finland (0.15), Hungary (0.16) and Portugal (0.16). Moreover, the distribution of relative markup is narrower in the countries with the lowest means of the mark-up indicating rather small market imperfections in these countries. On the other hand, the highest differences among producers can be found in Hungary and Romania, where the standard deviation is 0.115 and 0.123 , respectively. Hungary and Romania are characterized by large differences between the first and ninth deciles of the relative mark-up. This suggests that Hungarian milk processors with the highest mark-up could have considerable power to determine the market price and market environment, which could have a negative impact on companies with a small relative mark-up. A similar situation can also be found in Romania, Bulgaria, Spain, Portugal, Italy and France. In addition, the first decile for Romania and Bulgaria is very close to zero, suggesting that many companies are price takers in these countries.

Moreover, we can also find countries where non-competitive behaviour is significant for all dairy producers - Austria and the Netherlands. In these countries, the companies gathered in the first decile exercise significantly higher mark-up power than in the rest of the countries.

Figure 1 provides the development of relative mark-up in the EU output milk-processing market. We can observe a slight increase in the years 2007 and 2009, when the average value of mark-up increased similarly by 0.009 . Then, the mean value of mark-up decreased in 2010 and stabilized around the value 0.015. Moreover, Figure 1 shows that the spread between the first and ninth decile was pretty low in the year 2006. Then it significantly increased in 2007 and 2008 and became narrower over the next two years. The last year (2011) is characterized by another change. In particular, the mark-up differences among the companies started to increase again. This development suggests that the time of economic crises decreased the differences among the companies as far as relative mark-up is concerned. Specifically, we can observe a decrease in relative mark-up for companies with higher market power (ninth decile). The opposite is true for companies

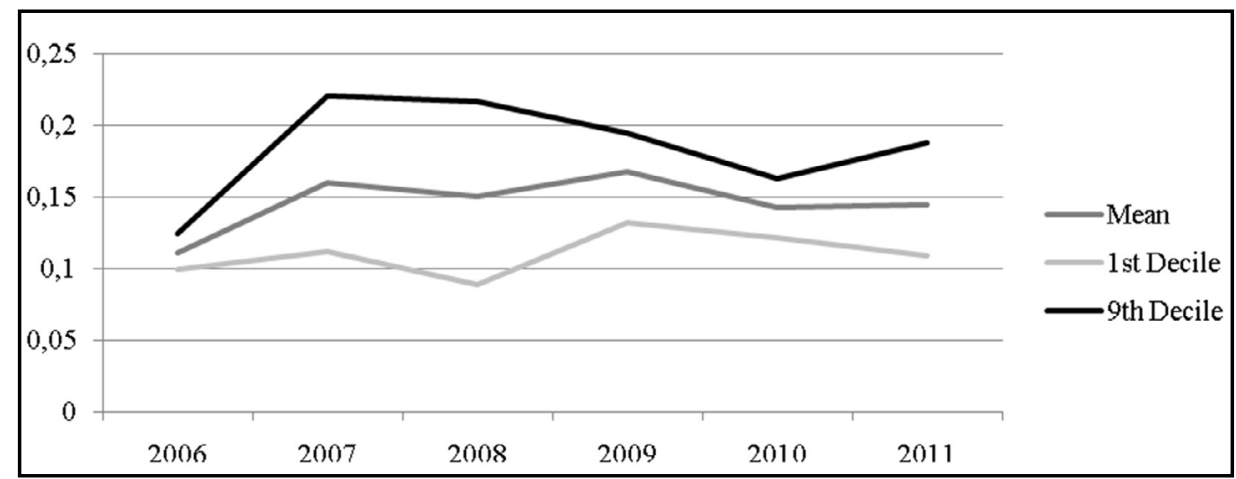

Note: Figure 1 presents the development of mark-up in the time period 2006-2011, for which there is a sufficient number of observations for each year.

Source: own calculation

Figure 1: Development of relative mark-up. 
in the first decile, i.e. companies with low relative mark-up.

The development of relative mark-up can also be analysed with respect to technical efficiency development, as provided in Kutlu and Sickles (2012). To analyse this relationship in the EU dairy sector, we can use the results of Cechura et al. (2014), who analysed the development of technical efficiency in European milk-processing companies. The results show that the technical efficiency of European milk processors decreased in 2007, 2008 and 2010 and increased in 2009 and 2011. That is, we can observe some similarities in the development of technical efficiency and relative mark-up, except for 2007. Since technical efficiency can be associated with the use of capacities, and taking into account the dairy market situation in the analysed period, the results suggest that the value of relative mark-up could be connected with the use of milk processors' capacities. On the other hand, the opposite development of technical efficiency and relative mark-up in 2007 could be associated with the role of management, in particular, "...firms may use their market power to allow inefficient allocation of resources." Kutlu and Sickles (2007, page 2).

Table 3 presents the mark-up development in the analysed countries. We can observe that the majority of EU member states have an almost identical development of the relative mark-up. The mark-up increased in 2007 and 2009 and decreased in 2010 and 2011. However, some exceptions can be found. The mark-up in the Netherlands, in particular, had an opposite development. It decreased in 2009 and increased in 2010 and 2011.

As far as the new member states are concerned, we can conclude that the relative mark-up mainly increased the year after the accession. Only the Czech Republic and Lithuania are exceptions. This could be the result of milk quotas, which strongly affected the situation in the milk market. This conclusion is supported by the increase in mark-up in the years of strong release of the quota (e.g. 2008 for the Czech Republic).

\begin{tabular}{|c|c|c|c|c|c|c|c|c|c|c|c|c|}
\hline Country & 2003 & 2004 & 2005 & 2006 & 2007 & 2008 & 2009 & 2010 & 2011 & 2012 & Trend function & $\mathrm{R}^{2}$ \\
\hline EU & 0.118 & 0.115 & 0.115 & 0.118 & 0.127 & 0.126 & 0.135 & 0.12 & 0.113 & 0.115 & $y=0.119-0.0002 t$ & 0.009 \\
\hline Austria & NA & NA & NA & 0.112 & 0.16 & 0.151 & 0.168 & 0.144 & 0.145 & NA & $y=0.133-0.004 t$ & 0.138 \\
\hline Belgium & 0.127 & 0.134 & 0.133 & 0.133 & 0.125 & 0.14 & 0.156 & 0.131 & 0.124 & NA & $\mathrm{y}=0.131+0.001 \mathrm{t}$ & 0.021 \\
\hline Bulgaria & 0.143 & 0.051 & 0.127 & 0.108 & 0.06 & 0.076 & 0.11 & 0.084 & 0.052 & NA & $y=0.118-0.006 t$ & 0.205 \\
\hline Czech Republic & 0.092 & 0.098 & 0.075 & 0.1 & 0.123 & 0.101 & 0.127 & 0.104 & 0.108 & 0.094 & $\mathrm{y}=0.092+0.002 \mathrm{t}$ & 0.128 \\
\hline Germany & 0.137 & 0.122 & 0.108 & 0.117 & 0.12 & 0.126 & 0.142 & 0.137 & 0.125 & 0.132 & $\mathrm{y}=0.12+0.001 \mathrm{t}$ & 0.132 \\
\hline Denmark & NA & NA & NA & NA & 0.109 & 0.121 & 0.159 & 0.09 & 0.102 & 0.139 & $\mathrm{y}=0.117+0.001 \mathrm{t}$ & 0.003 \\
\hline Estonia & 0.102 & 0.06 & 0.087 & 0.147 & 0.128 & 0.127 & 0.155 & 0.091 & 0.082 & 0.148 & $\mathrm{y}=0.092+0.004 \mathrm{t}$ & 0.117 \\
\hline Spain & 0.123 & 0.126 & 0.128 & 0.133 & 0.114 & 0.119 & 0.146 & 0.129 & 0.112 & 0.046 & $\mathrm{y}=0.143-0.005 \mathrm{t}$ & 0.256 \\
\hline Finland & 0.129 & 0.145 & 0.149 & 0.158 & 0.133 & 0.159 & 0.161 & 0.149 & 0.159 & NA & $\mathrm{y}=0.136+0.003 \mathrm{t}$ & 0.377 \\
\hline France & 0.146 & 0.138 & 0.138 & 0.147 & 0.148 & 0.137 & 0.136 & 0.131 & 0.126 & 0.096 & $y=0.155-0.004 t$ & 0.549 \\
\hline Great Britain & 0.084 & 0.074 & 0.08 & 0.087 & 0.079 & 0.076 & 0.078 & 0.073 & 0.068 & 0.078 & $y=0.083-0.001 t$ & 0.302 \\
\hline Greece & 0.091 & 0.103 & 0.1 & 0.114 & 0.118 & 0.118 & 0.127 & 0.121 & 0.104 & 0.136 & $\mathrm{y}=0.095+0.003 \mathrm{t}$ & 0.563 \\
\hline Hungary & 0.094 & 0.099 & 0.149 & 0.119 & 0.159 & 0.152 & 0.199 & 0.169 & 0.143 & NA & $y=0.098+0.009 t$ & 0.53 \\
\hline Italy & 0.131 & 0.127 & 0.133 & 0.133 & 0.133 & 0.133 & 0.157 & 0.141 & 0.13 & 0.155 & $y=0.126+0.002 t$ & 0.382 \\
\hline Ireland & NA & NA & 0.069 & 0.07 & 0.073 & 0.068 & 0.075 & 0.07 & 0.098 & NA & $\mathrm{y}=0.062+0.003 \mathrm{t}$ & 0.437 \\
\hline Latvia & 0.097 & 0.078 & 0.091 & 0.106 & 0.126 & 0.126 & 0.139 & 0.085 & 0.107 & 0.157 & $\mathrm{y}=0.084+0.005 \mathrm{t}$ & 0.347 \\
\hline Lithuania & 0.096 & 0.103 & 0.094 & 0.08 & 0.109 & 0.064 & 0.081 & 0.078 & 0.069 & 0.103 & $\mathrm{y}=0.098-0.002 \mathrm{t}$ & 0.123 \\
\hline Netherlands & 0.175 & 0.18 & 0.19 & 0.144 & 0.164 & 0.202 & 0.175 & 0.191 & 0.244 & 0.143 & $\mathrm{y}=0.171+0.002 \mathrm{t}$ & 0.208 \\
\hline Poland & 0.1 & 0.097 & 0.094 & 0.085 & 0.098 & 0.093 & 0.113 & 0.102 & 0.087 & NA & $\mathrm{y}=0.095+0.0002 \mathrm{t}$ & 0.007 \\
\hline Portugal & 0.192 & 0.165 & 0.171 & 0.17 & 0.162 & 0.166 & 0.172 & 0.136 & 0.123 & NA & $y=0.193-0.006 t$ & 0.662 \\
\hline Romania & 0.111 & 0.096 & 0.072 & 0.064 & 0.219 & 0.242 & 0.107 & 0.083 & 0.081 & NA & $\mathrm{y}=0.112+0.002 \mathrm{t}$ & 0.004 \\
\hline Sweden & 0.035 & 0.046 & 0.056 & 0.089 & 0.1 & 0.102 & 0.109 & 0.102 & 0.114 & NA & $\mathrm{y}=0.034+0.01 \mathrm{t}$ & 0.857 \\
\hline Slovenia & 0.119 & 0.087 & 0.09 & 0.088 & 0.131 & 0.16 & 0.172 & 0.154 & 0.125 & NA & $y=0.087+0.008 t$ & 0.419 \\
\hline Slovakia & 0.07 & 0.081 & 0.086 & 0.083 & 0.106 & 0.1 & 0.14 & 0.111 & 0.115 & NA & $y=0.067+0.007 t$ & 0.700 \\
\hline
\end{tabular}

Source: own calculation 
From the development in individual countries we can observe that the most significant decrease was in Estonia. On the other hand, the mark-up increased in Austria, the Czech Republic, Germany, Finland, Hungary, the Netherlands, Poland, Romania, Sweden, Slovenia and Slovakia. The highest increase was achieved in Slovenia, followed by Austria and Slovakia.

As far as the decile distribution development is concerned, we can observe that the companies in the $9^{\text {th }}$ decile in Estonia, France, Hungary, Romania and Slovenia significantly increased their market power in 2007 and then slightly decreased until 2010. This corresponds to the development on the EU level. Moreover, we can also find countries where the relative mark-up of the $9^{\text {th }}$ decile significantly increased during the analysed time period; however, the relative mark-up of the 1st decile decreased, namely in Sweden, Italy and Ireland. This suggests increasing differences among the companies with regard to abuse of market power in these countries. The opposite trend can be found in Austria, the Czech Republic, Germany, Denmark, Estonia, Spain, Portugal, Romania and Slovenia.

\section{Conclusion}

The European milk-processing market is characterized by some degree of market failure or abuse of market power, as the case may be. This abuse of oligopoly market power is not large, on average, but significant differences exist among the EU countries. Since the distribution of the mark-up is relatively narrow and skewed toward smaller values, the majority of milk processors are characterized by only a small or almost no degree of market power. On the other hand, $10 \%$ of producers reach a considerably high mark-up.

Focusing on the differences among EU countries,

Corresponding author:

Doc. Ing. Lukáš Čechura, Ph.D.

Department of Economics, Faculty of Economics and Management, Czech University of Life Sciences Prague Kamýcká 129, Prague 6, 165 21, Czech Republic

Phone: +420 224382303,E-mail: cechura@pef.czu.cz

\section{References}

[1] Acharya, R. N., Kinnucan, H. W., Caudill, S. B. Asymmetric farm-retail price transmission and market power: a new test. Applied Economics. 2011, Vol. 43, No. 30, p. 4759-4768. ISSN 0003-6846. we can specify a group of countries with very low oligopoly market power: Bulgaria, the United Kingdom, Lithuania and Sweden, and a group of countries with high oligopoly market power: Austria, Hungary, Finland and Portugal.

Relative mark-up power developed differently in these countries. The mark-up increased in Austria, the Czech Republic, Germany, Finland, Hungary, the Netherlands, Poland, Romania, Sweden, Slovenia and Slovakia in the analysed time period. The highest increase was achieved in Slovenia, followed by Austria and Slovakia. On the other hand, the most significant decrease was in Estonia.

The development of relative mark-up was connected with the development of the market situation. In particular, we can find similarities between the development of relative mark-up and technical efficiency, which could be associated with the use of milk processor capacities. Moreover, the development of relative mark-up power was influenced by government instruments such as milk quotas. Specifically, the mark-up increased in the years of strong release of the quota. Thus, the results suggest that the recent abolition of milk quotas may have a negative effect on competitive behaviour in the milk-processing market.

\section{Acknowledgments}

This paper was created within the project COMPETE - "International comparisons of product supply chains in the agro-food sectors: Determinants of their competitiveness and performance on EU and international markets". The project has received funding from the European Union's Seventh Framework Programme for research, technological development and demonstration under grant agreement no 312029 (www.compete -project.eu) and MSM 7E13038. 
[2] Alvarez, A., Arias, C., Greene, W. Fixed Management and time invariant technical efficiency in a random coefficient model. Working Paper, Department of Economics, Stern School of Business, New York University, 2003, p. 10.

[3] Alvarez, A., Arias, C., Greene, W. Accounting for unobservables in production models: management and inefficiency. Economic Working Papers at Centro de Estudios Andaluces E2004/72, Centro de Estudios Andaluces, 2004, p. 18.

[4] Bakucs, L. Z., Fertö, I., Hockmann, H., Perekhozhuk, O. Market power on the edge? An analysis of the German and Hungarian hog markets. Agrarwirtschaft. 2009, Vol. 58, Vol. 8, p. 337-345. ISSN 0002-1121.

[5] Bakucs, L. Z., Fertö, I., Hockmann, H., Perekhozhuk, O. Market power: Modelling issues and identification problems. An investigation of selected Hungarian food chains. Paper presented at $113^{\text {th }}$ EAAE Seminar "A resilient European food industry and food chain in a challenging world", Chania, Crete, Greece, date as in: September 3 - 6, 2009.

[6] Cechura, L., Hockmann, H., Kroupová, Z. Productivity and Efficiency of European Food Processing Industry, Compete Working Paper N7. September 2014. Available: <http://www.iamo.de/fileadmin/ compete/files/working_paper/COMPETE_Working_Paper_7_Productivity_FP.pdf> [Accessed: 20 January, 2015].

[7] Hockmann, H., Vönekim É. Collusion in the Hungarian market for raw milk. Outlook on Agriculture. 2009, 38, No. 1, pp. 39-45. ISSN 0030-7270.

[8] Jondrow, J., Knox Lovell, C. A., Materov, I. S., Schmidt, P. On the Estimation of Technical Inefficiency in the Stochastic Frontier Production Function Model, Journal of Econometrics. 1982, Vol. 19, p. 233-238. ISSN 0304-4076.

[9] Kumbhakar, S. C., Baardsen, S., Lien, G. A New Method for Estimating Market Power with an Application to Norwegian Sawmilling. Review of Industrial Organization. 2012, No. 40, p. 109-129. ISSN 0889-938X.

[10] Kutlu, L., Sickles, R. C. Estimation of market power in the presence of firm level inefficiencies. Journal of Econometrics. 2012, No. 168, p. 141-155. ISSN 0304-4076.

[11] Lerner, A. P. The concept of monopoly and the measurement of monopoly power. Review of Economic Studies. 1934, 1, No. 3, pp. 157-175. ISSN 1467-937X.

[12] McCorriston, S. Why should imperfect competition matter to agricultural economists?, European Review of Agricultural Economics. 2002, 29, pp. 349-371. ISSN 1464-3618.

[13] Morrison Paul, C. J. Cost Economies and Market Power: The Case of the U.S. Meat Packing Industry. The Review of Economics and Statistics. 2001, Vol. 83, No. 3, p. 531-540. ISSN 0034-6535.

[14] Muth, M. K., Wohlgenant, M. K. Measuring the Degree of Oligopsony Power in the Beef Packing Industry in the Absence of Marketing Input Quantity Data, Journal of Agricultural and Resource Economics. 1999, Vol. 24, p. 299-312. ISSN 1068-5502.

[15] Perekhozhuk, O., Grings, M. Measuring the degree of market power in the Ukrainian milk processing industry. In Curtiss, J., Balmann, A., Dautzenberg, K., Happe, K.. Studies on the Agricultural and Food Sector in Central and Eastern Europe, IAMO, Halle, Germany, 2006. p. 309-318.

[16] Perekhozhuk, O., Hockmann, H., Bakucs, L. Z., Fertö, I. Identification of market power in the Hungarian dairy industry: A plant-level analysis. Journal of Agricultural \& Food Industrial Organization. 2013, Vol. 11, No. 1, p. 1-13. ISSN 1542-0485.

[17] Scalco, P. R., Braga, M. J. Measuring the Degree of Oligopsony Power in the Brazilian Raw Milk Market. International Food and Agribusiness Management Review. 2014, Vol. 17, No. 2, p. 1-20. ISSN 1096-7508.

[18] Špička, J. The Competitive Environment in the Dairy Industry and its Impact on the Food Industry. Agris on-line Papers in Economics and Informatics. 2013, Vol. 5, No. 2, p. 89-102. ISSN 1804-1930. 
[19] Tsionas, E. G. Stochastic Frontier Models with Random Coefficients. Journal of Applied Econometrics. 2002, Vol.17, No. 2, p. 127-147. ISSN 1099-1255.

\section{Appendix}

\begin{tabular}{|c|c|c|c|c|c|c|c|c|c|c|c|}
\hline \multirow{2}{*}{$\begin{array}{l}\text { EU member } \\
\text { country }\end{array}$} & \multicolumn{2}{|c|}{ Revenue share } & \multicolumn{2}{|c|}{ Output } & \multicolumn{2}{|c|}{ Labour } & \multicolumn{2}{|c|}{ Capital } & \multicolumn{2}{|c|}{ Material } & \multirow{2}{*}{ Cases } \\
\hline & Mean & Std.Dev & Mean & Std.Dev & Mean & Std.Dev & Mean & Std.Dev & Mean & Std.Dev & \\
\hline Austria & 1.1954 & 0.0623 & 92737.91 & 92619.44 & 174.85 & 127.03 & 19220.31 & 20605.07 & 67505.84 & 64938.91 & 39 \\
\hline Belgium & 1.2259 & 0.1380 & 119009.53 & 158101.03 & 224.05 & 323.04 & 29010.03 & 98144.58 & 87911.66 & 116705.26 & 276 \\
\hline Bulgaria & 1.2732 & 0.2414 & 12750.47 & 12187.12 & 187.88 & 130.15 & 6477.57 & 5955.50 & 8338.91 & 6833.12 & 76 \\
\hline Czech Republic & 1.2276 & 0.1883 & 40169.18 & 44254.62 & 250.87 & 277.84 & 6329.18 & 7527.59 & 30976.20 & 34141.31 & 282 \\
\hline Germany & 1.1705 & 0.1686 & 204393.79 & 297311.04 & 327.98 & 623.94 & 29109.30 & 49245.12 & 165727.55 & 238507.13 & 414 \\
\hline Denmark & 1.1294 & 0.0817 & 2314193.09 & 3244577.21 & 5655.93 & 7881.13 & 806052.40 & 1137111.08 & 1837613.48 & 2568995.11 & 15 \\
\hline Estonia & 1.1853 & 0.1041 & 22060.50 & 12941.60 & 165.32 & 65.96 & 8859.25 & 4191.88 & 17200.97 & 10532.23 & 34 \\
\hline Spain & 1.2866 & 0.2335 & 97318.62 & 207871.39 & 217.55 & 389.85 & 33195.77 & 60794.21 & 59165.08 & 98875.76 & 570 \\
\hline Finland & 1.2035 & 0.1501 & 233762.15 & 556660.35 & 543.01 & 1296.52 & 60870.46 & 146832.59 & 160166.93 & 371622.12 & 84 \\
\hline France & 1.3375 & 0.2703 & 163090.07 & 363438.57 & 394.29 & 1221.47 & 37287.62 & 130303.10 & 103121.37 & 216797.25 & 623 \\
\hline Great Britain & 1.0692 & 0.1104 & 213097.92 & 414726.49 & 653.52 & 1424.41 & 65954.16 & 187000.12 & 174474.41 & 330398.53 & 450 \\
\hline Greece & 1.2145 & 0.1907 & 33124.48 & 51782.51 & 143.51 & 215.26 & 21551.84 & 40357.23 & 25126.31 & 33915.50 & 206 \\
\hline Hungary & 1.2847 & 0.1855 & 45867.35 & 41610.41 & 347.71 & 286.75 & 13412.99 & 19474.07 & 25799.00 & 26312.96 & 79 \\
\hline Ireland & 1.0363 & 0.0623 & 936141.31 & 1029748.10 & 1584.47 & 1726.40 & 334514.62 & 363620.58 & 799553.63 & 876715.06 & 17 \\
\hline Italy & 1.2548 & 0.1720 & 58544.38 & 280054.04 & 131.12 & 884.89 & 21966.70 & 132564.95 & 36715.53 & 137415.48 & 1666 \\
\hline Lithuania & 1.1988 & 0.1218 & 67461.16 & 63525.43 & 513.60 & 542.51 & 19391.36 & 20308.45 & 57503.08 & 53283.34 & 99 \\
\hline Latvia & 1.2132 & 0.1302 & 26954.79 & 21212.66 & 285.23 & 162.49 & 10694.06 & 8011.34 & 23017.85 & 18470.78 & 70 \\
\hline Netherlands & 1.1601 & 0.1326 & 743312.06 & 1157316.50 & 721.11 & 1789.57 & 111523.66 & 286703.80 & 692966.42 & 1099254.90 & 64 \\
\hline Poland & 1.1741 & 0.1506 & 43544.02 & 75287.36 & 270.84 & 264.81 & 11128.04 & 34450.71 & 34441.66 & 58196.16 & 754 \\
\hline Portugal & 1.3821 & 0.3090 & 54811.82 & 49628.36 & 221.63 & 179.63 & 22555.00 & 21683.09 & 30801.51 & 21691.28 & 75 \\
\hline Romania & 1.3469 & 0.2773 & 16167.80 & 21185.43 & 263.93 & 227.31 & 7339.68 & 9406.16 & 9909.07 & 11970.90 & 317 \\
\hline Sweden & 1.2651 & 0.2453 & 486515.00 & 699217.69 & 1288.93 & 1774.46 & 211794.57 & 303555.15 & 419235.93 & 608013.29 & 27 \\
\hline Slovenia & 1.1944 & 0.0645 & 85541.10 & 53874.98 & 364.63 & 264.64 & 34005.77 & 28643.02 & 64351.01 & 39421.62 & 27 \\
\hline Slovakia & 1.1531 & 0.0816 & 39086.04 & 30051.27 & 223.43 & 116.57 & 12510.88 & 9038.48 & 31360.52 & 25045.08 & 87 \\
\hline
\end{tabular}

Note: Output (ths. EUR), Labour (AWU), Capital (ths. EUR), Material (ths. EUR)

Source: own calculation

Appendix A.1: Sample descriptive statistics - dairy. 